\title{
How Important Is Liver Damage During COVID-19?
}

\author{
COVID-19 Sırasında Gelişen Karaciğer Hasarı Ne Kadar Önemli?
}

\section{Berat EBİK ${ }^{1}$ \\ (D) 0000-0002-0012-2505 \\ Nazım EKİN ${ }^{1}$ \\ (D) 0000-0001-5302-8953 \\ Ferhat BACAKSIZ ${ }^{1}$ \\ (D) 0000-0002-9670-3290 \\ Jihat KILIÇ ${ }^{2}$ \\ (iD) 0000-0003-3722-350X}

${ }^{1}$ Department of Gastroenterology, Gazi Yaşargil Education and Research Hospital, Diyarbakır, Turkey

${ }^{2}$ Department of Internal Medicine, Gazi Yaşargil Education and Research Hospital, Diyarbakır, Turkey

\section{Corresponding Author Sorumlu Yazar \\ Berat EBIKK \\ beratebik@gmail.com}

Received / Geliş Tarihi : 03.06.2021 Accepted / Kabul Tarihi : 29.09.2021 Available Online /

Çevrimiçi Yayın Tarihi : 23.11.2021

\begin{abstract}
Aim: The present study aimed to examine the prevalence of liver dysfunction in patients hospitalized due to coronavirus disease 2019 (COVID-19) and to investigate the role of liver dysfunction in predicting intensive care unit admission and mortality.

Material and Methods: A total of 2168 patients who had no previously known chronic liver disease and were found to be COVID-19 positive on polymerase chain reaction test were divided into mild and severe COVID-19 groups. The effect of the development of liver damage on the course and prognosis of COVID-19 was investigated.

Results: Elevated liver enzymes developed in 26.3\% $(n=461)$ of the patients with mild COVID-19 and in $45.3 \%(n=189)$ of the patients with severe COVID-19. The highest ALT and AST elevation was detected in patients using more than one drug with antibiotics $(\mathrm{p}<0.001)$. Severe hepatitis developed in $1.4 \%(\mathrm{n}=25)$ of the patients with mild COVID-19 and $6.5 \%(n=27)$ of the patients with severe COVID-19 $(\mathrm{p}<0.001)$. There was a weak negative correlation between ALT and albumin ( $\mathrm{p}=0.017, \mathrm{r}=-0.497)$, while a weak positive correlation with bilirubin $(\mathrm{p}=0.024, \mathrm{r}=0.352)$, a moderate positive correlation with ferritin $(\mathrm{p}=0.016$, $\mathrm{r}=0.504)$, and a weak positive correlation with INR ( $\mathrm{p}=0.022, \mathrm{r}=0.383)$ were found in patients with severe COVID-19.

Conclusion: The results showed that $30 \%$ of COVID-19 patients had impaired liver function of varying severity and that liver damage was more common in patients with severe COVID19. It was also determined that liver damage occurring during COVID-19 was an indicator of intensive care requirement and the mortality risk.
\end{abstract}

Keywords: COVID-19; liver; prognosis.

\section{ÖZ}

Amaç: Bu çalışma, koronavirüs hastalığı 2019 (coronavirus disease 2019, COVID-19) nedeniyle hastaneye yatırılan hastalarda karaciğer fonksiyon bozukluğu prevalansını incelemeyi ve yoğun bakım ünitesine yatış ve mortaliteyi öngörmede karaciğer fonksiyon bozukluğunun rolünü araştırmayı amaçlamaktadır.

Gereç ve Yöntemler: Önceden bilinen bir kronik karaciğer hastalığı olmayan ve polimeraz zincir reaksiyonu testi ile doğrulanmış COVID-19 pozitif olan toplam 2168 hasta, hafif ve şiddetli COVID-19 olarak gruplara ayrıldı. Karaciğer hasarı gelişiminin COVID-19'un seyrine ve prognozuna etkisi araştırıldı.

Bulgular: Hafif COVID-19'lu hastaların \%26,3'ünde ( $n=461)$ ve şiddetli COVID-19'lu hastaların \%45,3'ünde $(n=189)$ karaciğer enzimlerinde yükselme meydana geldi. En yüksek ALT ve AST artışları, antibiyotikler ile birlikte birden fazla ilaç kullanan hastalarda tespit edildi ( $p<0,001)$. Hafif COVID-19'lu hastaların \%1,4'ünde $(n=25)$ ve şiddetli COVID-19'lu hastaların \%6,5'inde $(n=27)$ şiddetli hepatit gelişti $(p<0,001)$. Şiddetli COVID-19'lu hastalarda, ALT ile albumin arasında zayıf düzeyde negatif bir korelasyon $(\mathrm{p}=0,017 ; \mathrm{r}=-0,497)$ saptanırken, bilirubin ile zayıf düzeyde pozitif bir korelasyon ( $\mathrm{p}=0,024 ; \mathrm{r}=0,352)$, ferritin ile orta düzeyde pozitif bir korelasyon $(\mathrm{p}=0,016 ; \mathrm{r}=0,504)$ ve INR ile zayıf düzeyde pozitif bir korelasyon ( $\mathrm{p}=0,022 ; \mathrm{r}=0,383$ ) olduğu saptand.

Sonuç: Sonuçlar, COVID-19 hastalarının \%30'unda farklı şiddette karaciğer fonksiyon testlerinde bozulma meydana geldiğini ve şiddetli COVID-19 hastalarında karaciğer hasarının daha yaygın olduğunu göstermektedir. Ayrıca COVID-19 sırasında meydana gelen karaciğer hasarının yoğun bakım gereksinimi ve ölüm riskini artıran bir etken olduğu da belirlenmiştir. Anahtar kelimeler: COVID-19; karaciğer; prognoz. 


\section{INTRODUCTION}

Coronaviruses are a virus family that primarily affect the human respiratory system, causing upper respiratory tract disease and pneumonia (1). To date, 7 types of coronaviruses that infect humans have been identified, including severe acute respiratory syndrome coronavirus-2 (SARS-CoV-2), which is known to cause coronavirus disease 2019 (COVID-19) (2). COVID-19 was first detected in 2019 in China and rapidly spread to the entire world and then was declared a global pandemic. At the time of writing, approximately 160 million COVID-19 cases had been diagnosed and more than 3.2 million deaths had been recorded (3). COVID-19 usually leads to death through respiratory failure, septic shock, and multi-organ failure, and over time more information and experience has been gained regarding the effect of COVID-19 on other organs. Liver damage in COVID-19 does not occur through a single mechanism. A leading cause of this damage is immunity-mediated damage which is formed as a result of a severe inflammatory response associated with COVID-19. All inflammation markers primarily including C-reactive protein (CRP), ferritin, lactate dehydrogenase (LDH), D-dimer, and interleukin (IL)- 6 have been shown to be elevated in such patients (4). Another mechanism of damage is the replication of the virus within hepatocytes and cholangiocytes on angiotensin-converting enzyme 2 (ACE-2) receptors found in the liver (5). Additionally, a frequently seen cause is drug-related liver disease and the reactivation of existing liver disease associated with the drugs used (6). In the liver biopsies of patients who died due to COVID-19, drug-related liver damage and abnormalities associated with shock and sepsis have been observed more often compared to other patients (7). In a previous study, presence of cellular apoptosis in different organs (lungs, liver, kidneys) was shown to be stimulated through pathways dependent on the caspase of protein $7 \mathrm{a}$, which is specific to the coronavirus family. The study also confirmed that the hepatocytes that were directly attacked by the SARS-CoV viruses caused liver damage (8).

The present study aimed to examine the prevalence of liver dysfunction in patients hospitalized due to COVID-19 and to investigate the role of liver dysfunction in predicting intensive care unit (ICU) admission and mortality.

\section{MATERIAL AND METHODS}

The study included 2168 patients that were hospitalized with a diagnosis of COVID-19 between April and December 2020. All the patients were found to be positive for COVID-19 on polymerase chain reaction (PCR) assay. An approval was obtained from the local ethics committee $(16.10 .2020,611)$ and an informed consent was obtained from each patient.

Patients that were previously diagnosed with chronic liver disease, patients that developed liver enzyme elevation and liver dysfunction during hospitalization, liver transplantation patients, patients with immunosuppressive therapy, patients with malignancy, and patients that had COVID-19 symptoms but had a negative PCR test were excluded from the study.

Patients that only had symptoms of fever, cough, headache, widespread joint pain, muscle pain, loss of smell and taste, and mild shortness of breath (respiratory count
$<20 /$ min and oxygen saturation $>92 \%$ ) were accepted as having mild COVID-19. As recommended in the guidelines, patients with severe tachypnea, oxygen saturation $<90 \%$, and low $\mathrm{PaO}_{2}$ according to blood gas analysis and severe respiratory and circulation problems requiring intensive care treatment were accepted as having severe COVID-19 (9). Based on this distinction, we examined the difference between patients with mild and severe COVID-19 in terms of liver dysfunction and the frequency of liver damage. In addition, we compared the liver functions of surviving and non-surviving patients as well.

Alanine aminotransferase (ALT) >35 U/L, aspartate aminotransferase (AST) $>40 \quad \mathrm{U} / \mathrm{L}$, gammaglutamyltransferase (GGT) $>45 \mathrm{U} / \mathrm{L}$, alkaline phosphatase $($ ALP) $>125 \mathrm{U} / \mathrm{L}$, total bilirubin (TBIL) $>1.2 \mathrm{mg} / \mathrm{dL}$, direct bilirubin (DBIL) $>1 \mathrm{mg} / \mathrm{dL}$, lactate dehydrogenase $>225$ $\mathrm{U} / \mathrm{L}$, Albumin $<4 \mathrm{mg} / \mathrm{dL}$, international normalized ratio (INR) $>1.2$, ferritin $>150 \mathrm{ng} / \mathrm{ml}$, and D-dimer $>243 \mathrm{ng} / \mathrm{ml}$ were accepted as abnormal values (10).

\section{Statistical Analysis}

Data were analyzed using SPSS v.26.0 for Windows (Armonk, NY: IBM Corp.). Normal distribution of data was assessed using Kolmogorov Smirnov test, skewness, and kurtosis. Categorical variables were expressed as frequencies (n) and percentages (\%). Continuous variables with normal distribution were expressed as mean \pm standard deviation (SD), and median (minimum-maximum) used for non-normal distribution. Normally distributed continuous variables were compared using Student's t test and parameters with non-normal distribution were compared using Mann-Whitney U test dichotomously. The difference in the distribution of categorical data between the groups was evaluated with the Pearson chi-square or Fisher's exact test, considering the number of patients in the categories. Post hoc Bonferroni correction was made in case of significance. Pearson correlation analysis was used according to their distribution to determine the correlation between continuous parameters. A two-tailed $p$ value of $<0.05$ was considered significant in all tests.

\section{RESULTS}

The 2168 patients comprised of 1125 (51.9\%) male and $1043(48.1 \%)$ female. Mild COVID-19 was diagnosed in $1751(80.8 \%)$ patients and severe COVID-19 was diagnosed in 417 (19.2\%) patients. Mortality developed in $252(11.6 \%)$ patients. Patients with severe COVID-19 had a significantly higher mean age (67.6 vs 43.6 years) and a significantly longer hospitalization duration (14.3 vs 7.1 days) compared to the patients with mild COVID-19 $(\mathrm{p}<0.001)$. No comorbidity was determined in $70.3 \%$ $(n=1525)$ of the patients and at least one comorbidity was present in the remaining $29.7 \%(n=643)$ of the patients. Most commonly seen two comorbidities were essential hypertension and diabetes mellitus (Table 1).

Elevated liver enzymes developed in $15.6 \%(n=32)$ of those using only hydroxychloroquine (HCQ); this rate was $13.8 \%(n=53)$ in patients who received favipiravir only. While ALT and AST elevation occurred in 28\% $(n=254)$ of the patients taking antibiotics; the highest ALT and AST elevation was detected in patients using more than one drug with antibiotics $(\mathrm{p}<0.001)$. Severe hepatitis developed 
in $1 \%$ of mild COVID-19 patients that used HCQ only and in $0.8 \%$ of patients that used favipiravir only. However, severe hepatitis developed in $1.8 \%$ of patients in whom antibiotics were added to the treatment (Table 2).

Elevated liver enzymes occurred in $26.3 \%(n=461)$ of patients with mild COVID-19, while in $45.3 \%(n=189)$ of severe COVID-19 patients. Severe hepatitis developed in $1.4 \%(n=25)$ of the patients with mild COVID-19 and $6.5 \%(\mathrm{n}=27)$ with severe COVID-19 ( $<<0.001$, Table 3$)$. On admission, the ALT, AST, ALP, and GGT levels were similar in surviving and non-surviving patients. At the end of treatment these levels were found to be significantly higher in non-surviving patients compared to surviving patients (Table 4).

There was a weak negative correlation between ALT and albumin ( $\mathrm{p}=0.017, \mathrm{r}=-0.497)$, while a weak positive correlation with bilirubin $(\mathrm{p}=0.024, \mathrm{r}=0.352)$, a moderate positive correlation with ferritin $(\mathrm{p}=0.016, \mathrm{r}=0.504)$, and a weak positive correlation with INR $(\mathrm{p}=0.022, \mathrm{r}=0.383)$ were found in patients with severe COVID-19. However no such correlation was found in patients with mild COVID-19 (Table 5).

Table 1. Demographic and clinical characteristics

\begin{tabular}{|c|c|c|c|}
\hline & Mild COVID-19 $(n=1751)$ & Severe COVID-19 $(n=417)$ & $\mathbf{p}$ \\
\hline Age (years), mean \pm SD (min-max) & $43.6 \pm 17.8(9-84)$ & $67.6 \pm 16.7(18-100)$ & $<0.001$ \\
\hline \multicolumn{4}{|l|}{ Gender, n (\%) } \\
\hline Male & $885(50.5 \%)$ & $240(57.6 \%)$ & \multirow{2}{*}{$\mathbf{0 . 0 1 0}$} \\
\hline Female & $866(49.5 \%)$ & $177(42.4 \%)$ & \\
\hline Days of hospitalization (days), median (min-max) & $7.1(1-30)$ & $14.3(3-79)$ & $<0.001$ \\
\hline \multicolumn{4}{|l|}{ Comorbid diseases, $\mathrm{n}(\%)$} \\
\hline None & $1376(78.6 \%)$ & $149(35.7 \%)$ & $<0.001$ \\
\hline DM & $162(9.2 \%)$ & $71(17.0 \%)$ & $<0.001$ \\
\hline HT & $187(10.7 \%)$ & $80(19.2 \%)$ & $<0.001$ \\
\hline More than one & $26(1.5 \%)$ & $117(28.1 \%)$ & $<0.001$ \\
\hline \multicolumn{4}{|l|}{ Used Drugs, n (\%) } \\
\hline HCQ & $398(22.7 \%)$ & $45(10.8 \%)$ & $<0.001$ \\
\hline Favipiravir & $1337(76.3 \%)$ & $401(96.1 \%)$ & $<0.001$ \\
\hline Antibiotics & $1274(72.7 \%)$ & $398(95.4 \%)$ & $<0.001$ \\
\hline Tocilizumab & $6(3.4 \%)$ & $154(36.9 \%)$ & $<0.001$ \\
\hline High dose steroid & $165(9.4 \%)$ & $316(75.7 \%)$ & $<0.001$ \\
\hline Oseltamivir & $78(4.4 \%)$ & $46(11.0 \%)$ & $<0.001$ \\
\hline Remdesivir & $1(0.05 \%)$ & $17(4.0 \%)$ & $<0.001$ \\
\hline İmmunoglobulin & $2(0.1 \%)$ & $13(3.1 \%)$ & $<0.001$ \\
\hline
\end{tabular}

Table 2. Relationship between the drugs used and the ALT levels in patients with mild COVID-19 ( $\mathrm{n}=1751)$

\begin{tabular}{|c|c|c|c|c|c|}
\hline & HCQ $(n=205)$ & Favipiravir $(n=386)$ & Antibiotics* $^{*}(\mathrm{n}=908)$ & Others $^{* * *}(n=252)$ & p \\
\hline \multicolumn{6}{|c|}{ ( : } \\
\hline Normal & $173(84.4 \%)$ & $333(86.2 \%)$ & $654(72.0 \%)^{\#}$ & $130(51.6 \%)^{\#}$ & \multirow{4}{*}{$<0.001$} \\
\hline 1-3 times higher (mild) & $28(13.6 \%)$ & $45(11.7 \%)$ & $223(24.6 \%)^{\#}$ & $107(42.4 \%)^{\#}$ & \\
\hline 3-5 times higher (moderate) & $2(1.0 \%)$ & $5(1.3 \%)$ & $15(1.6 \%)$ & $11(4.4 \%)$ & \\
\hline$>5$ times higher (severe) & $2(1.0 \%)$ & $3(0.8 \%)$ & $16(1.8 \%)$ & $4(1.6 \%)$ & \\
\hline
\end{tabular}

Table 3. Increase rates in ALT levels in patients with mild and severe COVID-19

\begin{tabular}{|c|c|c|c|}
\hline & Mild COVID-19 $(n=1751)$ & Severe COVID-19 $(n=417)$ & p \\
\hline \multicolumn{4}{|l|}{ ALT } \\
\hline Normal & $1290(73.7 \%)$ & $228(54.7 \%)^{\#}$ & \\
\hline 1-3 times higher (mild) & $403(23.0 \%)$ & $130(31.1 \%)^{\#}$ & \\
\hline 3-5 times higher (moderate) & $33(1.9 \%)$ & $32(7.7 \%)^{\#}$ & $<0.001$ \\
\hline$>5$ times higher (severe) & $25(1.4 \%)$ & $27(6.5 \%)^{\#}$ & \\
\hline
\end{tabular}

Table 4. Liver functions at the beginning and end of the treatment ${ }^{*}$

\begin{tabular}{|c|c|c|c|c|c|c|}
\hline & \multicolumn{2}{|c|}{ Surviving $(n=1916)$} & \multicolumn{2}{|c|}{ Non-surviving $(\mathrm{n}=\mathbf{2 5 2})$} & \multirow{2}{*}{$\mathbf{p}_{\text {B }}$} & \multirow{2}{*}{$\mathbf{p}_{\mathrm{A}}$} \\
\hline & Before & After & Before & After & & \\
\hline ALT & $25.9 \pm 25.6$ & $35.2 \pm 34.1$ & $25.5 \pm 16.8$ & $125.0 \pm 109.5$ & 0.309 & $<0.001$ \\
\hline AST & $24.1 \pm 20.6$ & $38.8 \pm 16.2$ & $28.6 \pm 24.1$ & $181.3 \pm 171.2$ & 0.125 & $<0.001$ \\
\hline GGT & $30.6 \pm 28.8$ & $36.9 \pm 42.8$ & $32.9 \pm 32.8$ & $58.1 \pm 48.7$ & 0.767 & 0.003 \\
\hline ALP & $87.5 \pm 30.3$ & $90.9 \pm 43.4$ & $91.2 \pm 38.7$ & $103.7 \pm 47.2$ & 0.098 & 0.028 \\
\hline
\end{tabular}

ALP: alkaline phosphatase, $\mathrm{p}_{\mathrm{b}}$ : before treatment, $\mathrm{p}_{\mathrm{a}}$ : after treatment between group $\mathrm{p}$ value 
Table 5. Correlation among liver functions

\begin{tabular}{|c|c|c|c|c|c|c|c|c|c|}
\hline & & \multicolumn{4}{|c|}{ Mild COVID-19 $(n=1751)$} & \multicolumn{4}{|c|}{ Severe COVID-19 $(n=417)$} \\
\hline & & Albumin & TBIL & Ferritin & INR & Albumin & TBIL & Ferritin & INR \\
\hline \multirow{2}{*}{ ALT } & $\mathrm{r}$ & -0.041 & 0.106 & 0.015 & 0.014 & -0.497 & 0.352 & 0.504 & 0.383 \\
\hline & $\mathrm{p}$ & 0.311 & 0.120 & 0.850 & 0.910 & 0.017 & 0.024 & 0.016 & 0.022 \\
\hline \multirow{2}{*}{ GGT } & $\mathrm{r}$ & -0.104 & 0.239 & 0.067 & 0.337 & -0.308 & 0.706 & 0.394 & 0.463 \\
\hline & $\mathrm{p}$ & 0.122 & 0.053 & 0.190 & 0.037 & $\mathbf{0 . 0 2 7}$ & 0.011 & 0.021 & 0.018 \\
\hline
\end{tabular}

COVID-19: coronavirus disease 2019, ALT: alanine aminotransferase, GGT: gamma-glutamyltransferase, TBIL: total bilirubin, INR: international normalized ratio

\section{DISCUSSION}

In this study, we found that $30 \%$ of patients who received COVID-19 treatment had elevated liver enzymes of varying degrees and we also noted that liver damage was more common in patients with severe COVID-19. Of note, the most common cause of liver enzyme elevation in patients with mild COVID-19 was the drugs used for the treatment. Isolated ALT and AST elevations were highly common in patients with mild COVID-19 and there was no correlation between these enzyme elevations and inflammation parameters. However, liver enzyme elevation was generally mild and transient in all patients. We also noted that patients with severe COVID-19 developed more severe liver dysfunction compared to patients with mild COVID-19. The most common cause of liver damage in these patients was systemic inflammation associated with cytokine storm and liver damage due to sepsis. We also found a correlation between inflammation markers and the severity of liver dysfunction in these patients, which implicates that the negative effect of increased inflammation on the liver is reflected in mortality.

A previous study investigated the relationship between COVID-19 and the liver and concluded that the liver dysfunction and liver damage in COVID-19 patients have a significant role in the prognosis of the disease (11). Another study reported that liver enzyme elevation that occurred during the disease indicated serious disease and the study also noted that albumin, which is a negative acute phase reactant, has a prognostic significance. In the present study, we found that the liver damage in COVID-19 pneumonia is more severe when compared to that of other viral pneumonias (12). In a meta-analysis with a large number of patients, liver function changes were reported in $47 \%$ of patients with COVID-19 and this situation was associated with in-hospital mortality (13).

Another meta-analysis reviewed 12,882 cases published in 24 studies that examined the relationship between COVID-19 and the liver, and found that $26.5 \%$ of the patients had liver damage. In addition, the study also showed that acute liver injury and elevated liver enzymes are significantly associated with the severity of COVID-19 (14).

It has been shown that liver damage due to COVID-19 is due to the direct cytopathic effect of the virus that is induced by the binding of virus to hepatocytes and cholangiocytes through ACE2 receptors. This damage predominantly occurs in cholangiocytes, which have an important role in both cell renewal and immune response (15). Meaningfully, this shows that GGT may elevate in severe COVID-19 patients (16). Similarly, in our study, a significant increase in GGT was noted, particularly in nonsurviving patients.

\section{CONCLUSION}

In conclusion, the results indicated that liver functions should be closely monitored in patients hospitalized due to COVID-19. Liver is known to have an extremely high functional reserve and it is also known that liver damage in COVID-19 can be in many different forms and can have a broad spectrum of manifestations. Abnormal liver functions that develop in patients with mild COVID-19 are typically mild and temporary and often do not pose a clinical problem. However, liver function abnormalities that develop in severe COVID-19 patients affect the prognosis of the disease. Therefore, attention should be paid to liver function disorders that develop in patients with severe COVID-19. It should also be noted that the drugs used in the treatment of patients with liver dysfunction have the potential of hepatotoxicity and widespread systemic inflammation, and thus alternatives for the treatment should always be readily available.

Ethics Committee Approval: The study was approved by the Ethics Committee of Gazi Yaşargil Education and Research Hospital (16.10.2020, 611).

Conflict of Interest: None declared by the authors.

Financial Disclosure: None declared by the authors.

Acknowledgements: None declared by the authors.

Author Contributions: Idea/Concept: BE; Design: FB; Data Collection/Processing: JK; Analysis/Interpretation: BE, NE; Literature Review: FB, JK; Drafting/Writing: BE; Critical Review: NE.

\section{REFERENCES}

1. Rahimi B, Vesal A, Edalatifard M. Coronavirus and its effect on the respiratory system: Is there any association between pneumonia and immune cells. $\mathbf{J}$ Family Med Prim Care. 2020;9(9):4729-35.

2. Niu P, Shen J, Zhu N, Lu R, Tan W. Two-tube multiplex real-time reverse transcription PCR to detect six human coronaviruses. Virol Sin. 2016;31(1):85-8.

3. Brüssow H. COVID-19 by numbers - infections, cases and deaths. Environ Microbiol. 2021;23(3):1322-33.

4. Liu J, Li S, Liu J, Liang B, Wang X, Wang H, et al. Longitudinal characteristics of lymphocyte responses and cytokine profiles in the peripheral blood of SARS-CoV-2 infected patients. EBioMedicine. 2020;55:102763. 
5. Chai X, Hu L, Zhang Y, Han W, Lu Z, Ke A, et al. Specific ACE2 expression in cholangiocytes may cause liver damage after 2019-nCoV infection. bioRxiv. 2020. doi: 10.1101/2020.02.03.931766.

6. Mantovani A, Beatrice G, Dalbeni A. Coronavirus disease 2019 and prevalence of chronic liver disease: a meta-analysis. Liver Int. 2020;40(6):1316-20.

7. Cai Q, Huang D, Yu H, Zhu Z, Xia Z, Su Y, et al. COVID-19: Abnormal liver function tests. J Hepatol. 2020;73(3):566-74.

8. Tan YJ, Fielding BC, Goh PY, Shen S, Tan TH, Lim $\mathrm{SG}$, et al. Overexpression of $7 \mathrm{a}$, a protein specifically encoded by the severe acute respiratory syndrome coronavirus, induces apoptosis via a caspasedependent pathway. J Virol. 2004;78(24):14043-7.

9. Casas-Rojo JM, Antón-Santos JM, Millán-NúñezCortés J, Lumbreras-Bermejo C, Ramos-Rincón JM, Roy-Vallejo E, et al. Clinical characteristics of patients hospitalized with COVID-19 in Spain: results from the SEMI-COVID-19 Registry. Rev Clin Esp (Barc). 2020;220(8):480-94.

10. EASL-ALEH Clinical Practice Guidelines: Noninvasive tests for evaluation of liver disease severity and prognosis. European Association for the Study of the Liver. J Hepatol. 2015;63(1):237-64.
11. Kulkarni AV, Kumar P, Tevethia HV, Premkumar M, Arab JP, Candia R, et al. Systematic review with metaanalysis: liver manifestations and outcomes in COVID-19. Aliment Pharmacol Ther. 2020;52(4):58499.

12. Zhao D, Yao F, Wang L, Zheng L, Gao Y, Ye J, et al. A comparative study on the clinical features of coronavirus 2019 (COVID-19) pneumonia with other pneumonias. Clin Infect Dis. 2020;71(15):756-61.

13. Del Zompo F, De Siena M, Ianiro G, Gasbarrini A, Pompili M, Ponziani FR. Prevalence of liver injury and correlation with clinical outcomes in patients with COVID-19: systematic review with meta-analysis. Eur Rev Med Pharmacol Sci. 2020;24(24):13072-88.

14. Sharma A, Jaiswal P, Kerakhan Y, Saravanan L, Murtaza Z, Zergham A, et al. Liver disease and outcomes among COVID-19 hospitalized patients - A systematic review and meta-analysis. Ann Hepatol. 2021;21:100273.

15. Xu L, Liu J, Lu M, Yang D, Zheng X. Liver injury during highly pathogenic human coronavirus infections. Liver Int. 2020;40(5):998-1004.

16. Alqahtani SA, Schattenberg JM. Liver injury in COVID-19: The current evidence. United European Gastroenterol J. 2020;8(5):509-19. 